\title{
Developing Economics Learning Materials for Independent Learning During Covid-19
}

\author{
Junaidi H. Matsum ${ }^{1 *}$ \\ ${ }^{I}$ Teacher Training and Education Faculty, Tanjungpura University Pontianak, Ahmad Yani Street, Pontianak, West \\ Borneo, Indonesia \\ *Corresponding author. Email: prof.junaidimatsum@gmail.com
}

\begin{abstract}
In the era of Covid-19 pandemic, the teachers are demanded to implement an action plan to maintain learning. To minimize the inequalities and negative effects of prolonged inactivity, the teachers must set clear and realistic learning materials by taking into account the sudents' characteristics, social environment, and learning problems. This research aims to develop economics learning materials for independent learning of Senior High School students in accordance with the curriculum syllabus 2013. The method used is educational research and development involving the steps: preliminary studies, model development, and model experiment. In arranging steps, selection, structuralism, charaterization, and reduction are systematically done. The population are taken from economics teacher and the students of SMAN 1 Sambas Regency. Cluster sampling is used for sampling technique. The data are collected through direct communication and documentation technique. The conclusion reveals that there is economics book was composed for students independent learning. The developed learning materials are suitable based on expert judgement, peer review, and experiment to the students.
\end{abstract}

Keywords: Learning materials, economics, standard competencies, independent learning.

\section{INTRODUCTION}

In this unprecendented times, the learning circumstances have been switched onto online learning. This form of learning is a quintessential adaptive and transformative challenge not only for students but also for the teachers. One of the things that should be taken into account by the teachers is to arrange the materials that suit the students the most, in order to create personalized as well as adaptive learning for online learning activities. Thus, the need to develop the innovative materials is becoming a demand to optimize online learning process. Girik Allo [1] asserted that creative and innovative, lecturers are required to keep students informed of proper education and teaching.

To develop learning materials for online activity that is suitable with curriculum 2013 is not straightforward. It requires in depth analysis along with motivation and carefulness from the stakeholders [2].. Hence, analysis of curriculum materials is needed to avoid mistakes that might occur. Errors in evaluating the syllabus competency of a curriculum material both in terms of completeness as well as accuracy can cause the weak quality of the curriculum. By referring to the facts above, in order to assist teachers/authors of economic textbooks in developing and organizing material in a whole, systematic, and logical way, it is necessary to develop economic learning materials that can be used as a source of economic subjects in schools. For this reason, Research and Development (R\&D) was conducted: the development of economic learning materials (specialization) for independent study of high school students during the Covid-19 Pandemic. The problem of this research was "How to develop economic learning materials (specialization) for independent learning of SMA Negeri 1 Kecamatan students Sambas in the Covid-19 Pandemic Period. This study aims to develop economic learning materials (specialization) for independent learning of SMA Negeri 1 Sambas subdistricts even semester 2019/2020 in the Covid-19 Pandemic Period which is of good quality and in accordance with the basic competencies of the syllabus of economic students (specialization) curriculum 2013.

\section{LITERATURE REVIEW}

\subsection{Curricullum Implementation}

There are several factors that should be taken in mind when developing a curriculum implementation strategy. Susilo [3] argued that there are broadly three factors that influence curriculum implementation, namely: program development, learning implementation, and evaluation. The development of the national curriculum (curriculum 2013) is explained in the syllabus of subjects. Mulyasa [4] stated that in principle the syllabus contains six elements, namely: (1) competency standards, (2) basic competencies, (3) competency indicators or indicators of competency achievement, (4) standard materials, standards process (learning activities, and (6) assessment standards. Meanwhile, to develop a syllabus according to Mulyasa [4] it is necessary to pay attention to the principles of scientific, relevant, flexible, continuity, consistent, adequate, actual and contextual, and effective and efficient. 


\subsection{Learning Materials}

Generally speaking, learning materials are the most substantial and observable components of pedagogy $[5,6]$. Defined learning material as teaching tools arranged in a complete and systematic way based on the principles used by teacher and students in the learning process. Learning materials contain facts, concepts, principles, and relevant procedures, and are written in the form of items in accordance with the formulation of competency achievement indicators. Siddiq, et al. [7] suggested that learning materials are arranged in a systematic way, showing a wholeness of the competencies to be achieved by students in learning. Factors that need to be considered in developing learning materials according to the Ministry of National Education (2011) namely: (1) Competency Indicators and Learning Objectives. (2) Characteristics of learning materials. (4) Student factors, (5) Facilities, Media, and Learning Resources. (6) The principles of developing learning materials, namely: the principle of relevance, consistency, and adequacy. (7) Steps to choose learning materials, including: (a) identify aspects of competency standards and basic competencies to guide learning material selection, (b) identify types of learning materials, (c) choose learning materials that are consistent with competency and competency standards the basis; and (d) determine the source of learning material.

\section{METHODS}

This research employed educational research and development modified from R\&D Borg and Gall which include stages: (1) Preliminary Study, (2) Model Development, and (3) Model Testing [8]. This research was carried out in SMAN1 Kecamatan Sambas. The teacher and student who are officially enrolled in economic learning (specialization) of eleventh grades science class were used as subject of research. The type of instrument used were: researcher, structured interview guidelines, and test. The preliminary study was conducted with (a) document study in the form of curriculum analysis of economic subjects (specialization), analysis of students' abilities in the appropriate content and context, and (b) study of economic literacy literature. Field studies were carried out by interviewing economics teachers (specialization). The development phase is an activity to produce revised learning materials based on the validator's suggestion.

The stages of preparing teaching materials in this study follow the steps mentioned by Anwar (2010), including: (a) Selection of various sources and adjusted to the curriculum currently being used; (b) Structuring the map of teaching material concepts that are arranged in a structured and systematic manner in one subject; (c) Characterization, in which learning materials are analyzed each concept, determined which is simpler, close to student life, concretely, then slowly the level the difficulty is increased; (d) Reduction is done by ignoring things that are considered complicated the use of analogies that change things that are abstract into relatively more concrete.
Meanwhile, the model test steps include: (1) Arranging the prototype design, consisting of the preparation of the text, format, and form of the material according to the results of the needs analysis and also the preparation of the learning design; (2) prototype validation test by the validator to assess and give consideration to both criticism and suggestions; (3) revision of the prototype which include the improvement of the final product and the revision of the results of the previous trial; (4) limited trials to test the effectiveness of high school economics (specialization) prototype learning materials; (5) The results of product development in the form of economic learning materials (specialization) for students independent learning during the Covid-19 Pandemic era. Analysis of research data was in the form of qualitative and quantitative descriptive analysis techniques. to process data validation results of learning materials by the validator. The research instruments were arranged in the form of a Likert scale, the analysis was using quantitative descriptive which the researchers grouped the data into three ranges, namely (1) a range of $3.00 \leq \leq 4.00$ (very valid), (2) a range of $2.00 \leq x$ $<3,00$ (valid), (3) range $1.00 \leq x<2.00$ (less valid).

\section{RESULTS AND DISCUSSION 4.1 Results}

By referring to the result of the development, it revealed that learning materials used for students independent learning in the era of Covid-19 pandemic was in line with the basic syllabus of curriculum 2013.

The basic competencies developed in economic learning materials (specialization) of class XI were in accordance with the competency standards in the syllabus of the 2013 curriculum, namely: (1) Describe the Concept of Economic Development, Problems and How to Overcome It; (2) Describe the difference between economic development and economic growth, how to measure economic growth, and economic growth theory; (3) Describe Labor in Indonesia, (4) Explain Labor Problems in Indonesia; (5) Describe the National Income, Concept, Method of Calculation of National Income and Its Benefits; (6) Present the Results of Calculation of National Income; (7) Describe the State Budget in Development and Evaluate Its Role on the Economy; (8) Describe the APBD in development and evaluate its role in the economy; (9) Analyzing the role, functions and benefits of taxes; (10) Analyzing the role, functions and benefits of taxes; (11) Describe Price and Inflation Indexes; (12) Analyzing Price and Inflation Indexes; (13) Describe monetary and fiscal policy, and their roles and functions. (14) Describe monetary and policy policies and their roles and functions; (15) Describe business entities in the Indonesian economy; (16) Describe the Capital Market in the Economy; (17) Describe the capital market in the economy; (18) Describe the concepts and policies of international trade; (19) Describe International Trade; (20) Analyzing international economic cooperation; and (21) Describe International Cooperation. 
Table 1 Average Validator Assessment Results Against Economic Learning Materials (Specialization) High School Grade XI for Each Validated Item

\begin{tabular}{|c|c|c|}
\hline No & Validated Indicators/ Items & Average \\
\hline A. & Content of Learning Materials & \\
\hline 1. & $\begin{array}{l}\text { Learning materials contain facts, concepts, principles, and relevant procedures, and are written in } \\
\text { the form of items in accordance with the formulation of competency achievement indicators. }\end{array}$ & 3,66 \\
\hline 2. & $\begin{array}{l}\text { Learning materials are arranged in a systematic way, showing a wholeness of the competency } \\
\text { standards and basic competencies that will be achieved by students in learning. }\end{array}$ & 3,66 \\
\hline B. & Relevancy Principle & \\
\hline 3. & $\begin{array}{l}\text { There is a match between learning materials and the achievement of competency standards and } \\
\text { basic competencies. }\end{array}$ & 3,66 \\
\hline 4. & $\begin{array}{l}\text { Learning objectives are in accordance with indicators of achievement of competencies that } \\
\text { students must master }\end{array}$ & 3,66 \\
\hline 5. & $\begin{array}{l}\text { The learning materials chosen to be taught by teachers are in line with competency indicators } \\
\text { that students must master }\end{array}$ & 3,66 \\
\hline 6. & $\begin{array}{l}\text { Learning materials that students learn contain material or teaching materials that really support } \\
\text { the achievement of competency standards and basic competencies }\end{array}$ & 3,66 \\
\hline 7. & $\begin{array}{l}\text { The examples contained in the learning material are in accordance with the competencies that } \\
\text { will be achieved by students. }\end{array}$ & 2,34 \\
\hline 8. & Illustrations on learning materials are aligned with learning objectives & 2,34 \\
\hline 9. & $\begin{array}{l}\text { The extent of the description of the discussion of learning materials according to the level of } \\
\text { student development }\end{array}$ & 3,66 \\
\hline 10. & $\begin{array}{l}\text { The exercises that students will do are intended to deepen students' understanding of learning } \\
\text { materials }\end{array}$ & 2,34 \\
\hline 11. & Formative test items are relevant to learning objectives and learning material & 2,34 \\
\hline C. & Consistency Principle & \\
\hline 12. & $\begin{array}{l}\text { There is a difference between learning material and basic competencies that students must } \\
\text { master }\end{array}$ & 3,66 \\
\hline D. & Adequacy Principle & \\
\hline 13. & Learning materials are adequate to help students master the specified basic competencies & 3,66 \\
\hline 14. & Learning materials are relatively quite in accordance with the teaching duration & 3,66 \\
\hline E. & Accuracy Principle & \\
\hline 15. & Learning materials are in line with scientific truth & 3,66 \\
\hline 16. & Learning materials in accordance with everyday life & 3,66 \\
\hline 17. & Packaging learning materials in accordance with an economic scientific approach & 3,66 \\
\hline 18. & Learning materials are arranged in accordance with the development of science and technology & 2,34 \\
\hline F. & Systematics of Writing Learning Materials & \\
\hline 19. & Material description follows the flow of thought from easy to difficult & 3,66 \\
\hline 20. & Material description follows the flow of thought from simple to complex. & 3,66 \\
\hline 21. & Material description follows the mindset from the local to the global sphere & 3,34 \\
\hline 22. & Presenting competencies students must master & 3,66 \\
\hline 23. & Presenting learning objectives & 3,66 \\
\hline 24. & $\begin{array}{l}\text { Presenting material discussion in accordance with learning objectives and indicators of } \\
\text { competency achievement }\end{array}$ & 3,66 \\
\hline 25. & Present a summary & 3,66 \\
\hline 26. & Present illustrations, examples, images & 2,34 \\
\hline 27. & $\begin{array}{l}\text { Contains practical questions and instructions how to do them to increase students' understanding } \\
\text { of the material }\end{array}$ & 3,34 \\
\hline 28. & $\begin{array}{l}\text { Contains test items with answer keys and scoring guidelines for each learning activity so that } \\
\text { students can assess themselves }\end{array}$ & 3,66 \\
\hline 29. & $\begin{array}{l}\text { Include an explanation if the student reaches the level of mastery of the value of mastery } \\
\text { learning economics or more students can continue with the next learning activity. But if it is still } \\
\text { below the completeness value, students must repeat the learning activities, especially the part } \\
\text { that has not been mastered }\end{array}$ & 3,66 \\
\hline
\end{tabular}




\begin{tabular}{|c|c|c|}
\hline No & Validated Indicators/Items & Average \\
\hline 30. & $\begin{array}{l}\text { Presenting a glossary for each learning activity, is an explanation of words (terms) that are } \\
\text { considered difficult / difficult for students to understand so that additional explanations need to } \\
\text { be given. Such as foreign / regional words and terms }\end{array}$ & 3,34 \\
\hline 31. & Present preface/forewords & 3,66 \\
\hline 32. & Presents table of contents. & 3,66 \\
\hline 33. & Presenting the torso which is divided into chapters / sections & 3,66 \\
\hline 34. & Contains various learning resources and are listed in the bibliography. & 3,66 \\
\hline H. & The relevance of the presentation to the demands of student-centered learning & \\
\hline 35. & Motivate students' curiosity & 3,34 \\
\hline 36. & Motivate student interaction with learning resources & 3,34 \\
\hline 37. & Motivate students to build their own knowledge & 3,34 \\
\hline 38. & Motivate students to learn in groups & 3,66 \\
\hline 39. & Motivate students to practice learning materials & 2,34 \\
\hline I. & Presentation approach & 3,34 \\
\hline 40. & Support the growth of student reasoning & 3,34 \\
\hline 41. & Support the growth of students' critical thinking & 3,34 \\
\hline 42. & Supports logical thinking & 3,34 \\
\hline J. & Conformity of Language with the rules of Indonesian Good and Correct & \\
\hline 43. & Spelling accuracy & 3,66 \\
\hline 44. & Accuracy in terms of use & 3,66 \\
\hline 45. & Accuracy in structuring sentences & 3,34 \\
\hline 46. & The material is presented by paying attention to the rules of sentence structure & 3,34 \\
\hline 47. & The material is presented using effective sentences. & 3,34 \\
\hline K. & Readability and Communicability & \\
\hline 48. & The length of the sentence in accordance with the level of understanding of students & 3,34 \\
\hline 49. & Sentence structure in accordance with student understanding & 3,34 \\
\hline 50. & Making paragraphs in accordance with student understanding & 3,34 \\
\hline 51. & The language used is formal language & 3,66 \\
\hline 52. & $\begin{array}{l}\text { The language used is in accordance with the level of knowledge and the level of development of } \\
\text { students' understanding of thinking ability (clear vocabulary, correct diction, and use of correct } \\
\text { spelling) }\end{array}$ & 3,66 \\
\hline 53. & $\begin{array}{l}\text { The language used in learning materials is in accordance with students' social-emotional } \\
\text { situation (age and environment). }\end{array}$ & 3,66 \\
\hline 54. & The language used is communicative & 3,66 \\
\hline \multicolumn{2}{|r|}{ Average } & 3,09 \\
\hline
\end{tabular}

Table 1 depicts that the overall average value is 3.09 , which means it is included in the very valid category. When viewed per item statement there are still 5 (five) items out of 54 items that are included in the valid criteria, namely item number 7 (seven), which is a statement about the examples contained in the learning material in accordance with the competencies to be achieved by students; item number 8 (eight) is a statement about the illustrations on the learning material in harmony with the learning objectives, item number 10 whose statement about the exercises to be done by students is intended to deepen students' understanding of the learning material, item number 11 about relevant formative test items with learning objectives and learning materials, and item number 39 about Motivating students to practice learning materials. The results of the validator's assessment of the economic learning materials (specialization) of class XI SMA for each indicator are presented in Table 2 below.

Table 2 Average Results of Validator Assessment of Economic Learning Materials (Specialization) High School Grade XI for Each Indicator

\begin{tabular}{|c|l|c|}
\hline No & \multicolumn{1}{|c|}{ Validated Indicators/ Items } & Average \\
\hline A. & Content of Learning Materials & 3,66 \\
\hline B. & Relevancy Principle & 3,45 \\
\hline C. & Consistency Principle & 3,66 \\
\hline D. & Adequacy Principle & 3,66 \\
\hline
\end{tabular}




\begin{tabular}{|c|l|c|}
\hline No & \multicolumn{1}{|c|}{ Validated Indicators/Items } & Average \\
\hline E. & Accuracy Principle & 3,33 \\
\hline F. & Systematics of Writing Learning Materials & 3,51 \\
\hline J. & Conformity of Language with the rules of Indonesian Good and Correct & 3,46 \\
\hline K. & Readability and Communicability & 3,51 \\
\hline & Average & $\mathbf{3 , 0 9}$ \\
\hline
\end{tabular}

From table 2 above, it is known that the sum of the values in each indicator is very valid and the average value of the three validators is 3.09 , which means it is included as a very valid criterion. The feasibility of the developed economic learning materials (specialization) is declared feasible based on the results of expert judgment and expert judgment of the material, psychology, and language that reviews them from the appropriateness of the contents, content of learning materials, principles of developing learning materials, systematic writing of learning materials, the relevance of the presentation to the demands of learning studentcentered, presentation approaches; the suitability of the language with the rules of Indonesian language that is good and right, legibility and communicative.

The next phase of the activity is to test the model. In this case, the learning materials that have been prepared are tested on a limited and broad basis with students. The results of limited and extensive trials are shown in Table 1 below.

Table 3 Test Results for Using Economic Learning Materials (Specialization) Class XI High School on a Limited and Broad Scale of Students

\begin{tabular}{|c|c|c|c|c|}
\hline Activity number & Testing & Total of Student & Students Pass & Students did not pass \\
\hline 1 & Limited & 18 & 12 & 6 \\
\hline & Broad & 35 & 26 & 9 \\
\hline 2 & Limited & 23 & 18 & 5 \\
\hline 3 & Broad & 45 & 36 & 5 \\
\hline & Limited & 28 & 23 & 8 \\
\hline
\end{tabular}

Table 3 depicts that after the first limited trial, the use of economic learning materials (specialization) and a post-test of 18 students was obtained by students who completed 12 people $(66.67 \%)$ and who did not complete 6 people (33, $33 \%$ ) while in the large-scale trial activity of 35 students, 25 students $(71.42 \%)$ completed students and 9 students (28.58\%) incomplete.

In the second limited testing activity, the use of economic learning materials (specialization) and conducted a posttest of 23 students obtained 18 students who completed 18 (78.26\%) and 5 people $(21.74 \%)$ incomplete while in the large scale testing activities of 45 students obtained students who completed 37 people $(80.00 \%)$ and those who did not complete 8 people $(20.00 \%)$.

Then in the third limited testing activity, the use of economic learning materials (specialization) and conducted a posttest of 28 students obtained students who completed 23 people $(82.14 \%)$ and unfinished 5 people $(17.86 \%)$ while in the scale testing activities broad of 70 students obtained students who completed 62 people $(88.57 \%)$ and 8 students who did not complete $(11.43 \%)$. Thus, the use of economic learning materials (specialization) developed for independent learning of class XI students of SMA Negeri 1 Sambas District is effective.

Some input from the validator of the material expert, pedagogic expert, and linguist for the perfection of economic learning materials (specialization) in class XI of high school that have been developed are (1) Examples contained in the learning materials in accordance with the competencies that students will achieve are reproduced; (2), it is necessary to add illustrations to learning materials in harmony with the learning objectives (3) Item questions exercises to be done by students aimed at deepening students' understanding of learning materials should be relatively large; (4) Option options for formative test items should be more than three; (5) The compiled learning materials should be more adapted to the development of science and technology; and (6) Class errors in typing letters, lack of letters, and placement of new paragraphs need to be revised.

Based on the above input, the learning material is revised according to the validator's suggestions. After being repaired then consulted again with the validators. Based on the results of expert judgment and expert judgment, that the learning material developed has fulfilled the aspect of validity, it was finally declared worthy to be used in the learning process of economic learning (specialization) in high school for independent and effective learning to improve learning outcomes.

\subsection{Discussion}

Research outcomes was in the form of economic learning materials (specialization) for independent study of high school students during the Covid-19 pandemic era according to basic competencies in the syllabus of the 2013 curriculum. The development was declared suitable for use. This is in accordance with research result from Putri [9] concluded that the development of competency-based teaching materials for School Mathematics 1 stated that the teaching materials had met the validity indicators and had 
been revised in accordance with the validator's suggestion so that the teaching materials were appropriate to be used and could be used as teaching materials in School Mathematics 1 lectures. The research recommendations were indicated for further researchers to develop competency-based teaching materials for other subjects. In other words, it is also necessary to research the development of other learning materials.

Good learning materials can improve student learning outcomes. The results of this study are supported by a statement from the Ministry of National Education [2] that learning materials are useful to help teachers carry out learning activities. For teachers, learning materials are needed to direct all activities and which should be taught to students in the learning process. The learning material is a module that is designed to help students master their learning goals and as a means of student learning independently according to their respective speeds. Furthermore, Lestari [10] proposed learning material which is a set of subject matter guided by the curriculum that is used to achieve predetermined competency standards and basic competencies. From the above statement it can be stated that if the learning material is considered valid it can affect the success of students in learning and ultimately improve their learning outcomes.

\section{CONCLUSION}

\subsection{Conclusion}

a. There are outcomes in the form of economic learning materials (specialization) for independent study of high school students during the 19th Copid pandemic that are in accordance with the basic competencies in the 2013 curriculum syllabus.

b. Economic learning materials (specialization) of class XI students of SMA Negeri 1 Sambas Subdistrict developed according to the results of expert judgment, peer reviewers, and trials of students and effective in improving student learning outcomes. and effective in improving student learning outcomes.

\subsection{Suggestion}

It is expected that the developed learning material can be a source of economic learning (specialization) for independent learning of class XI high school students.

\section{ACKNOWLEDGEMENT}

A special gratitude for SMAN 1 Kabupaten Sambas for allowing the researcher to carry out the research.

\section{REFERENCES}

[1] M. D. G. Allo, "Is the online learning good in the midst of Covid-19 Pandemic ? The case of EFL learners," J. Sinestesia, vol. 10, no. 1, pp. 1-10, 2020.

[2] Ministery of Education, Kurikulum 2013. Jakarta: Depdiknas, 2013.

[3] M. J. Susilo, Kurikulum Tingkat Satuan Pendidikan Manajemen Pelaksanaan dan Kesiapaan Sekolah Menyongsongnya. Yogyakarta: Pustaka Pelajar, 2012.

[4] E. Mulyasa, Kurikulum Tingkat Satuan Pendidikan. Bandung: Remaja Rosdakarya, 2018.

[5] M. B. D. A. A. A. Andi Tenri Ampa, "The Development of Contextual Learning Materials for the English Speaking Skills," Int. J. Educ. Res., vol. 1, no. 9, pp. 1-10, 2013.

[6] M. W. Kurniawati, S. Anitah, and S. Suharno, "Developing Learning Science Teaching Materials Based on Scientific to Improve Student Learning Outcome in Elementary School," Eur. J. Educ. Stud., no. 20, pp. 319-330, 2017, doi: 10.5281/zenodo.398991.

[7] D. Siddiq, M. Djauhar, Pengembangan Bahan Ajar. Direktorat Jendral Pendidikan Tinggi Depdiknas, 2008.

[8] N. . Sukmadinata, Metode Penelitian Pendidikan. Bandung: Rosdakarya, 2015.

[9] F. M. Putri, "Pengembangan Bahan Ajar Berbasis Kompetensi Matakuliah Matematika Sekolah I," Algoritm. J. Math. Educ., vol. 1, no. 1, pp. 44-53, 2019, doi: 10.15408/ajme.v1i1.11685.

[10] I. Lestari, Pengembangan Bahan Ajar Berbasis Kompetensi (Sesuai dengan Kurikulum Tingkat Satuan Pendidikan). Padang: Academic Press, 2013. 